\title{
Experience of source isolation during hospitalization - a qualitative study
}

\author{
AF Madsen \\ From 3rd International Conference on Prevention and Infection Control (ICPIC 2015) \\ Geneva, Switzerland. 16-19 June 2015
}

\section{Introduction}

This study explored and describes the factors that may influence how patients react to source isolation from others during hospitalization.

\section{Objectives}

The study also sought to determine how background variables such as gender, age and previous hospitalization affect source isolation.

\section{Methods}

This qualitative study used content analysis to review data collected from interviews with five patients.

- The conceptual framework describes antibiotic resistance and infection control from a public health perspective and explored its prevention in Denmark.

- The theoretical framework describes how patients experience an infection acquired by exposure to drugresistant bacteria, as well as subsequent isolation.

\section{Results}

The limited space, lack of contact with people resulted in patient monotony and anxiety.

- Women showed greater concern about precautions against infection, and about risk of transmitting disease to visitors.

- Men outwardly resigned themselves to the situation and did not speculate about infection precautions. Men had a more rational approach, and tended to cope better when isolated.

- Younger patients seemed to have better coping strategy during isolation.

- Elderly patients felt sad and lonely.

- Patients developed their own strategies for coping with source isolation.

Department of Clinical Microbiology, Rigshospitalet, Copenhagen, Denmark

\section{Conclusion}

Hospitals need more alternatives (e.g., better training and improved treatment) to prevent negative psychological affects due to isolation without compromising infection prevention. Hospitals should update their personnel at all organization levels, and focus on room facilities in the ward, contact time and improved information. Risk assessment should be individualized for each patient.

\section{Disclosure of interest}

None declared.

Published: 16 June 2015

doi:10.1186/2047-2994-4-S1-P95

Cite this article as: Madsen: Experience of source isolation during

hospitalization - a qualitative study. Antimicrobial Resistance and

Infection Control 2015 4(Suppl 1):P95.
Submit your next manuscript to BioMed Central and take full advantage of:

- Convenient online submission

- Thorough peer review

- No space constraints or color figure charges

- Immediate publication on acceptance

- Inclusion in PubMed, CAS, Scopus and Google Scholar

- Research which is freely available for redistribution 